\title{
LEMBAGA MUSYAWARAH GANTI KERUGIAN DALAM REZIM HUKUM PERTANAHAN NASIONAL PENGADAAN TANAH PEMBANGUNAN JALAN TOL CINERE-JAGORAWI KOTA DEPOK
}

\author{
Slamet Riyady, Chessa Ario Jani Purnomo \\ Fakultas Hukum Universitas Pamulang \\ E-Mail: dosen02101@unpam.ac.id
}

\begin{abstract}
Abstrak
Tentang Penggiatan (Pengadaan) Tanah Untuk Pembangunan Demi Kepentingan Universal terpaut Lembaga musyawarah ganti kerugian adalah sumber hukum formal yang bersifat abstrak-umum. Oleh sebab itu, secara logis tidak diatur mengenai tata cara dan akibat hukum bagi para pihak. Penelitian ini menggunakan metode socio - legal research, memandang hukum sebagai gejala sosial dimasyarakat berdasarkan kajian hukum dan studi lapangan, hasil penelitian Tegasnya, perihal praktik musyawarah pengadaan tanah pembangunan jalan tol cijago kota depok masyarakat menganggap belum adanya musyawarah untuk mufakat melainkan pernyataan sikap panitia pengadaan tanah atas hasil penilaian menjadikan dasar penetapan ganti kerugian, berangkat hal tersebut terdapat kekeliruan pemahaman terhadap prinsif pelakaksanaan musyawarah dalam rezim hukum pertanahan nasional.
\end{abstract}

Kata Kunci: musyawarah; ganti kerugian; pengadaan tanah.

\begin{abstract}
Concerning Activation (Procurement) of Land for Development for Universal Interests linked to Indemnity deliberation institutions is a source of formal law that is general and abstract. Therefore, logically it does not regulate the legal procedures and consequences for the parties. This research uses the socio-legal research method, views law as a social symptom in the community based on legal studies and field studies, the results of the research. Strictly speaking, regarding the practice of deliberation for land acquisition for the construction of the Cijago toll road, Depok city, the community thinks that there is no deliberation to reach a consensus but rather a statement of the attitude of the land acquisition committee. Based on the results of the assessment, the basis for determining compensation, departing from this, there is a misunderstanding of the principles of implementing deliberation in the national land law regime.
\end{abstract}

Keywords: delibration; convensation; land acquisition. 


\section{Pendahuluan}

Imam Koeswayono mengkritisi rancangan undang-undang pengadaan tanah untuk pembangunan yang saat ini sudah diundangkan jadi Undang- Undang No 2 Tahun 2012 Tentang Pengadaan Tanah Untuk Pembangunan Buat Kepentingan Universal( Berikutnya diucap UU Nomor. 2 Tahun 2012) serta berlaku secara nasional. Setidaknya, kritik Imam terdapat pada 2 (dua) aras paradigmatik yakni: pertama, permasalahan pertanahan berwatak struktural karena terjadi ketimpangan penguasaan/pemilikan tanah. Kedua, penyempitan diskursus pertanahan terkait makna kepentingan umum. ${ }^{1}$

Secara sosiologis, sifat struktural yang disroroti di atas berdampak kepada praktik ganti kerugian dalam hukum pertanahan. Dikatakan demikian, bahwa mengingat hubungan pemerintah dan masyarakat mengandung ketimpangan relasi kekuasaan sehingga terbuka lebar potensi paksaan sepihak oleh pemerintah. Keberadaan hukum yang bersifat paksaan merupakan suatu hukum yang represif, senada dengan itu Nonet dan Selznick berpendapat : 'views government power as repressive, if that power does not pay attention to the interests of the people being governed, that is, power is exercised not for their interests, or by denying the legitimacy of the community'2

Bernhard Limbong, menyadari buat mengendalikan pertanahan berpijak dari, "Pasal 33 ayat( 3)" Undang- Undang Dasar 1945 yang menegaskan kalau Bumi, air serta, kekayaan alam yang tercantum didalamnya dipahami oleh Negeri buat dipergunakan untuk sebesar- besar kemakmuran rakyat. Setelah itu, bunyi statment ini diselesaikan secara kuat didalam Undang- Undang No 5 Tahun 1960 tentang Peraturan Dasar Pokok- Pokok Agraria,( Lembaran Negeri 1960- 104 ataupun diucap.) ${ }^{3}$ Selaras dengan kepentingan umum dalam pengadaan tanah Maria .S.W, Sumardjono, berpendapat merujuk : "Keputusan Presiden Nomor 55 Tahun 1993 kegiatan pengadaan tanah sebagai kepentingan seluruh lapisan masyarakat, sedangkan mengenai kegiatan pembangunan untuk kepentingan umum dibatasi pada kegiatan pembangunan yang dilakukan dan selanjutnya dimiliki oleh pemerintah serta digunakan tidak mencari keuntungan"4.

\footnotetext{
${ }^{1}$ Koeswahyono, Imam. "Mengkritisi rancangan undang-undang pengadaan tanah untuk kepentingan pembangunan, suatu catatan kritis." Jurnal Hukum \& Pembangunan 41.2 (2011): 243-257.

2 Yesmil Anwar \& Adang, Pengantar Sosiologi Hukum, Grasindo, Jakarta, Cetakan Ketiga, 2017. hlm. 159.

${ }^{3}$ Bernhard Limbong, Pengadaan Tanah Untuk Pembangunan ( Regulasi, Kompensasi, Penegakan Hukum, Margaretha Pustaka, Jakarta, 2011, hlm. 39.

${ }^{4}$ Maria SW, Sumardjono, Kebijakan Pertanahan Antara Regulasi Dan Implementasi, Kompas, Jakarta, 2001,hlm. 73.
} 
Pada kenyataanya hukum pertanahan tidak cukup ampuh menengahi ketegangan tersebut sebab lembaga musyawarah pada Kegiatan (Pengadaan) Tanah mengatur secara abstrak-umum. Tanpa mekanisme. Tegasnya, perihal musyawarah tergantung kepada kekuatan/modal para pihak. Hal ini memaksa Pemerintah harus menghormati, melindungi, menegakan, serta memajukan hak masyarakt tergusur oleh kegiatan (Pengadaan) tanah, Merujuk Pasal 72: "Kewajiban dan tanggungjawab pemerintah meliputi langkah implementasi yang efektif dalam bidang hukum, politik, ekonomi, sosial, budaya, pertahanan keamanan negara, dan bidang lain" Dengan demikian, terbuka peluang untuk memikirkan, mendiskusikan dan merefleksikan BAB IV Pasal 37 UU No. 2 Tahun 2012 terkait lembaga musyawarah terhadap ganti kerugian. Oleh sebab itu, penulis merebahkan pandangan kepada Pancasila dan Undang-Undang Dasar Negara Republik Indonesia 1945 sebagai titik awal argumentasi. Mencermati sila- sila yang tercantum dalam Pancasila dengan jelas serta tegas mengakui eksistensi nilai- nilai kemanusian baik individual ataupun kolektivitas sehingga HAM dalam Pemikiran Pancasila merupakan mengakui eksistensi nilai- nilai kemanusian yang wajib dihormati serta dihargai ${ }^{5}$

Berkaitan dengan musyawarah Menurut Syamsudin salah satu warga yang terkena pembanguan tol cijago Pada 6 April 2017 warga diundang musyawarah dibale kota depok oleh BPN Depok untuk musyawarah. Faktanya, Kepala BPN Depok menyatakan warga yang setuju silahkan ajukan permberkasan dengan penilaian 2015 dan bagi yang tidak setuju silahkan gugat penilai statement Kantah Depok bapak Almaini. 2 Nov 2017, warga audiensi dengan warga wakil walkot depok dan tidak ditemani oleh Lawyer ke PN Depok telah dikonsinyasi. ${ }^{6}$

Penulis meyakini, dari sisi pemerintah dalam hal ini Lembaga Pertanahan menginsyafi nilai-nilai Pancasila dan Konstitusi R.I sebagai sumber kekuasaan dan kewenangan mereka. Pada saat yang sama bagi masyarakat terdampak (istilah UU No. 2 Tahun 2012 adalah pihak yang berhak) memberikan legitimasi melalui Konsititusi itu kepada pemerintah dengan harapan proses pelepasan hak atas tanah mereka dikompensasi secara layak. Sederhana sekali. Akan tetapi, dalam proses hukum formal dilihat dari sudut yuridis-empiris atau socio-legal studies, ada banyak varabel atau kekuatan-kekuatan sosial yang berlaku, beroperasi dan mempengaruhi atas proses hukum formal itu. Sehingga proses musyawarah tidak lagi sederhana.

${ }^{5}$ Nurul Qamar, Hak Asasi Manusia Dalam Negara Hukum Demokrasi, Jakarta, Sinargrafika, Cetakan Ketiga, 2016, hlm. 94.

${ }^{6}$ Hasil Wawancara, Dengan Bapak Syasudin Selamet, Pada Tanggal Kamis 3 September 2020. 
Setelah menelusuri permasalahan yang terjadi dalam upaya kegiatan pembebasan tanah guna pembangunan jalan tol cijago Kota Depok yang berdasarkan prinsif keseimbangan dapat dirumuskan beberpa masalah antaralain: 1) bagaimanakah pelaksanaan musyawarah kegiatan (pengadaan) tanah, untuk kepentingan umum rezim pertanahan tol cijago Kota Depok ? Kedua, bagaimana musyawarah mufakat bisa tidak terjadi dalam proses pergantian kerugian sebelum pelepasan tanah milik warga?

\section{Permasalahan}

Setelah menelusuri permasalahan yang terjadi dalam upaya kegiatan pembebasan tanah guna pembangunan jalan tol cijago Kota Depok yang berdasarkan prinsif keseimbangan dapat dirumuskan beberpa masalah antaralain Pertama, bagaimanakah pelaksanaan musyawarah kegiatan (pengadaan) tanah, untuk kepentingan umum rezim pertanahan tol cijago Kota Depok ? Kedua, bagaimana musyawarah mufakat bisa tidak terjadi dalam proses pergantian kerugian sebelum pelepasan tanah milik warga?

\section{Metode Penelitian}

Sebagai penelitian sosiologis ( socio-Legal research ) data yang digunakan data Primer adalah hasil wawancara dari pejabat Kantor Pertanahan Kota Depok dan Juga Masyarakat yang terkena ganti kerugian akibat pengadaaan tanah tersebut yang didukung dengan Peraturan Menteri Keuangan Nomor 02/ PMK 06/2008 Tentang Penilaian Barang Milik Negara

\section{Pembahasan}

\section{Perkembangan Prinsif Kepentingan Umum Pengadaan Tanah Dalam Rezim} Hukum Pertanahan Nasional

Sebelum penulis memaparkan prinsif kepentingan umum Pada pengadaan tanah ada baiknya, terlebih dahulu kita uraikan pengertian pengadaan tanah dalam kepentingan umum. Setelah lahirnya Undang-Undang Nomor 2 Tahun 2012 tentang Pengadaan Tanah Bagi Pembangunan Untuk Kepentingan Umum Pasal 1 angka 2 mendefinisikan pengadaan tanah sebagai berikut : Pengadaan tanah adalah kegiatan menyediakan tanah dengan cara memberi ganti kerugian yang layak dan adil kepada pihak yang berhak. ${ }^{7}$

Sesuai denga istilah di atas Boedi Harsono Menyatakan : "mengatakan pengadaan tanah merupakan Perbuatan hukum yang berupa melepaskan hubungan hukum yang semula ada antara pemegang hak dan tanahnya yang

7 H.M. Arba, Hukum Pengadaan Tanah Untuk Kepentingan Umum, Jakarta, Sinar Grafika, 2019, hlm,14 
diperlukan, dengan pemberian imbalan dalam bentuk uang, fasilitas atau lainnya, melalui musyawarah untuk mencapai kata sepakat antara empunya tanah dan pihak yang memerlukan."

Pengadaan tanah filosofisnya adalah pengadaan tanah untuk kepentingan umum, tetapi kepentingan umum sebagai suatu konsep tidak sulit dipahami tetapi tidak mudah dipahami ${ }^{9}$ sebenarnya makna kepentingan umum terdapat dalam Pasal 18 UUPA, menyebutkan bahwa: "untuk kepentingan umum, termasuk kepentingan Bangsa dan Negara, serta kepentingan bersama dari rakyat, hak - hak atas tanah dapat dicabut, dengan memberi ganti kerugian yang layak dan menurut cara yang diatur dengan Undang - Undang". ${ }^{10}$

Pada pelaksanaannya pasal tersebut diatur dalam Undang - Undang Nomor 20 Tahun 1961 Tentang Pecabutan Hak Atas Tanah dan Benda- Benda yang Ada Di Atasnya. Berdasarkan penjelasan di atas dapat dipahami bahwa sesuai dengan UUPA dan Undang - Undang Nomor 20 Tahun 1961 Tentang Pecabutan Hak Atas Tanah dan Benda- Benda yang Ada Di Atasnya, Adrian Sutedi memberikan pandangan mengenai makna peruntukannya untuk kepentingan Bangsa dan Negara, Kepentingan bersama dari Rakyat, dan kepentingan pembangunan, yang dirasakan kemanfaatannya oleh masyarakat baik secara langsung maupun tidak langsung ${ }^{11}$.

Selanjutnya prase kepentingan umum atau secara universal, juga kita temui sebagai seluruh lapisan masyarakat, sedangkan mengenai kegiatan pembangunan untuk kepetingan umum dibatasi oleh pemerintah serta tidak digunakan untuk tidak hanya sekedar mencari keuntungan semata saja hal ini berkaitan dengan doktrin tentang kepentingan oleh Michiel G.Kitay umum menjadi dua yaitu, "General guidelines (general guide), and the provisions of the list (List Provisions, while the term,public purpose, may change, for example, public becomes a need, necessity, interest, function, utility or use, the country that uses, this general guideline, is usually not explicit, it does not include in the laws and regulations what fields of activity are referred to as, public interest,.It is the court that casuistically determines what is called" public interest "12.

8. Boedi Harsono, Hukum Agraria Indonesia, Sejarah Pembentukan UndangUndang Pokok Agraria, Isi dan Pelaksanaannya, Djembatan, Jakarta,1995,hlm. 7.

${ }^{9}$ Maria SW, Sumardjono, Op Cit.,hlm.72.

${ }^{10}$ Pasal 18 Undang- Undang No 5 Tahun 1960 Tentang Peraturan Dasar Pokok - Pokok Agraria.

${ }^{11}$ Adrian Sutedi, Implementasi Prinsip Kepentingan Umum Di Dalam Pengadaan Tanah Untuk Kepentingan Umum, Sinar Grafika, Jakarta, 2020, hIm. 417.

${ }^{12}$ Adrian Sutedi, Implementasi Prinsip Kepentingan Umum Di Dalam Pengadaan Tanah Untuk Kepentingan Umum, Sinar Grafika, Jakarta, 2020, hlm. 81. 
Pada kenyataanya pemahaman publik mengenai kepentingan umum terkait dengan beberapa hal mendasar yakni adanya keuntungan sosial berupa msyarakat umum atau luas akan menikmati tujuan pembebasa lahan dilakukan oleh pemerintah dan tidak beroerentasi pada profit.

Berbeda dengan pandangan masyarakat dalam Perpres No 36 Tahun 2005, terdapat prinsip yang dapat ditarik mengenai benar - benar suatu kegiatan untuk kepentingan umum meliputi :1)Jika Kalau aktivitas tersebut benar- benar dipunyai oleh pemerintah, dalam kalimat tersebut memiliki batas kalau aktivitas kepentingan universal tidak bisa dimilki oleh perorangan maupun swasta,2) Aktivitas pembangunan terpaut dijalankan pemerintah, tidak mencari keuntungan dalam prase ini jelas menghalangi sesuatu guna tentang sesuatu aktivitas universal sehingga benar- benar berbeda dengan kepentingan swasta yang buat mencari keuntungan sehingga terkualifikasi kalau aktivitas buat kepentingan universal sama sekali tidak boleh mencari keuntungan.

Kegiatan tersebut benar-benar dimiliki oleh pemerintah, dalam kalimat tersebut mengandung batasan bahwa kegiatan kepentingan umum tidak dapat dimilki oleh perorangan ataupun swasta, Kegiatan pembangunan terkait dilakukan oleh pemerintah, tidak mencari keuntungan dalam prase ini jelas membatasi suatu fungsi tentang suatu kegiatan umum sehingga benar - benar berbeda dengan kepentingan swasta yang untuk mencari keuntungan sehingga terkualifikasi bahwa kegiatan untuk kepentingan umum sama sekali tidak boleh mencari keuntungan.

Apabila kita baca penjelasan terkait aturan tersebut memaknai suatu perumusan terkait Kepentingan Umum sama dengan suatukepentingan Bangsa, yang di rasakan oleh masyarakat dengan diwujudkan melalui pemerintah guna kemakmuran rakyat.

\section{Musyawarah Di Dalam Penyelenggaraan Pengadaan Tanah Dalam Rezim Hukum Pertanahan Nasional Khususnya Tol Cijago Depok}

Prinsip yang dianut dalam Rezim hukum Pengadaan Tanah di Indonesia adalah Tiada Pengadaan Tanah Tanpa Musyawarah, Prinsip ini tertuang dengan jelas dalam Ketentuan Pasal 37 mengenai adanya Lembaga Pertanahan dalam hal ini adalah BPN ( badan Pertanahan Nasional) wajib menjalankan musyawarah terhadap para Pihak memiliki batas waktu paling lambat adalah 30 (tiga puluh) hari ,kerja setelah hasil dari Penilai disampaikan dalam rangka memberikan serta menetapkan bentuk besarnya Ganti. Oleh sebab itu penulis memandang keberadaan suatu proses musyawarah sebagaimana dimaksud aturan tersebut sifatnya menjadi keharusan atau kewajiban yang tidak boleh ditinggalkan dalam sistem kegiatan (Pengadaan) Tanah khususnya untuk umum. 
Oleh sebab itu banyaknnya keracuhan atas proses musyawarah dalam keigatan (Pengadaan ) tanah tersebut Penulis mencemati dalam penyelenggaran pengadaan tanah untuk kepentingan umum terkait dengan perselisihan yang terjadi dalam menentukan bentuk dan besaran ganti rugi perlu adanya pemikiran bahwa penyelesaian yang paling utama harus dilakukan dengan cara ADR ( Alternatif Dispute Resolution) yaitu musyawarah, berupa mediasi serta negosiasi.

Musyawarah sendiri menurut beberapa pandangan akademisi salah satunya Suruh Roiqoh"Musyawarah pengambilan keputusan dalam bentuk referendum yang melibatkan semua anggota masyarakat atau rakyat di satu negara, juga bisa dinilai dalam bentuk lain dari musyawarah, hal ini tampak dalam Piagam Madinah yang di antara diktum menegaskan perlunya bermusyawarah untuk saling memberi nasehat serta saran dalam kebaikan dan melakukan kerja sama dalam bidang pertanahan"13

Musyawarah di dalamnya bisa dilakukan dengan negosiasi, mediasi dan konsultasi, hal tersebut memberikan pemikiran dalam bermusyawarah Sayud Margono berpandangan untuk terwujudnya musyawarah harus dengan komunikasi dua arah yang dirancang atas mencapai kesepakatan pada saat kedua belah pihak memiliki berbagai tujuan baik sifatnya sama ataupun yang berbeda14., senada dengan teknik dalam musyawarah Jimmy Joses Sembiring mengutarakan ada 5 teknik negosiasi, yaitu dengan teknik negosiasi kompetetif, kooperatif, negosiasi lunak, negosiasi keras serta negosiasi interest based ${ }^{15}$

Adapun terdapat proses yang identik dengan penyelesaian sengketa dengan cara melalui kesukarelaan sering juga disebut sebagai mediasai atau perundingan, 16 namun serta ada juag proses yang menjadi bagian makna musyawarah salah satunyanegosiasi penyelesaian dengan cara memasukan pihak luar bersifat netral untuk bersengketa dengan tujuan mendapatkan capaian - capaian atassuatu kesepakatan memuaskan para pihak ${ }^{17}$ serta yang

${ }^{13}$ Suruh Roiqoh, "Pengadaan Tanah Untuk Kepentingan Umum (Kajian Perbandingan Antara Hukum Islam dalam Konsep Maslaha Mursalah dan Undang-Undang Nomor 2 Tahun 2012)", Tesis pada Fakultas Hukum Universitas Islam Indonesia, Yogyakarta, 2013

14 Susilawetty, Arbitrase Dan Alternatif Penyelesaian Sengketa Ditinjau Dalam Persepektif Peraturan Perundang - Undangan, Gramata Publishing, Jakarta, 2013, hlm. 18.

15 Jimmy Joses Sembiring, Cara Menyelesaiakan Sengketa Diluar Pengadilan, Trans Media Putaka, Jakarta, 2011,hlm. 20.

16 Jimmy Joses Sembiring, Op.Cit., hlm. 28.

${ }^{17}$ D.Y. Witanto, Hukum Acara Mediasi Dalam Perkara Perdata Umum Dan Peradilan Agama Menurut Perma NO 1 Tahun 2008 Tentang Prosedur Mediasi Di Pengadilan, Bandung, Alfabeta, 2011,hlm, 28 
terakhir biasa disebut dengankonsultasi ${ }^{18}$, Konsultasi sudah diatur dengan Pasal 18 dimana dilaksanakan dengan melibatkan atau menyertakan para pemegang kepentingan bisa dikategorikan tim pengadaan serta lembaga yang lainya seperti BPK, serta masyarakat yang terkena dampak bisa juga dengan kuasanya bisa menunjukan surat kuasa ${ }^{19}$

Hal senada Ali Sofwan Husein "berpendapat dalam pelaksanaan pergantian kerugian harus diberikan kesempatan, saluran, dorongan dan arahan yang berguna untuk mengekspresikn hak dan kewajibannya itu secara proposiona bila ganti rugi yang diberikan itu kecil, tidak wajar dan tidak layak itu harus dipaksakan masyarakat menerima ganti rugi tersebut sementara tidak kesepakatan dalam musyawarah" 20 Pada penelitian ini, penulis temukan musyawarah tersebut berubah menjadi pengarahan-pengarahan serta Upayaupaya memperlemah posisi pemegang hak atas tanah dengan ketentuan ganti kerugian, serta kurangnya kemauan politik dari pemerintah untuk menghormati hak-hak perseorangan.

Menurut bapak Samsudin sebagai wakil ketua pelaksana pengadaan tanah P2T Tol Cijago Seksi II Kota Depok, terjadinya penolakan warga itu, adalah terkait nilai mereka menganggap masih dibawah harga pasaran, padahal setahu saya sudah ada perbiakan nilai dari tahun ketahun sebelumnya dan sebenarnya tidak ada kendala . namun yang menjadi Kendalanya hanya beda pemahaman musyawarah berdasarkan UU dan Warga, kami BPN menjalankan UU nah warga memahami musyawarah itu tawar menawar, oleh sebab itulah perlu aturan memperjelas tata cara musyawarah pengadaan tanah itu agar sengketa - sengketa kaya gini gak ada lagi kedepanya pumgkasnya.

Terbalik lurus dengan penjelasan musyawarah di atas H. Ahmad Roji, warga yang terkena pengadaan tanah, beralamat di Jalan Joglo No. 2, RT. 001/RW 007, Kelurahan Kukusan , Kecamatan Beji, Kota Depok Memberikan Keterangan yang menerangkan bahwa : "warga kukusan dan bakti jaya yang terkena dampak proyek tol Cinere - Cijago di undang hadir dalam penyampaian hasil Apraisal pada tanggal 27 April 2017, sedangkan Penilaian Publik dilakukan pada 30 November 2015 kami hanya di undang tidak ada berita acara hasil musyawarah, dan kami juga tidak pernah menerima berita acara kesepakatan. "2l Fakta tersebut harus dijadikan dasar untuk perbaikan kedepan.

18 D.Y. Witanto,Op.Cit., hlm.15.

19 Pasal 19 Undang-Undang Nomor 2 Tahun 2012 Tentang Pengadaan Tanah Untuk Kepentingan Umum

${ }^{20}$ Ali Sofwan Husein, Komplik Pertanahan, Pustaka Sinar Harapan, Jakarta, 1997, hlm. 50.

${ }^{21}$ Wawancara Dengan Bapak Syamsudin Selamet, Roni, Serta Warga Yang Terkena Pergantian Kerugian Tol Cijago, Pada Hari Sabtu Tanggal 12 September 2020 


\section{Simpulan}

Pelaksanaan musyawarah dalam kegiatan (pengadaan) tanah yang terjadi dalam kasus Tol Cijago Kota Depok secara formalitas sudah dilaksanakan namun secara esensial tidak terpenuhi ini ditandai dengan adanya penolakan nilai ganti kerugian dari warga yang terkena dampak kegiatan (pengadaan) tanah untuk kepentingan umum dengan mengajukan gugatan kepada Pengadilan Negeri Depok dengan No: 45 / Pdt.G/2018 /PN/Dpk. Serta tidak tercapainya mufakat dalam musyawarah tersebut karena dilaksanakan hanya dalam legal formal saja tidak memenuhi nilai-nilai esensi dalam musyawarah, negosiasi, mediasi dan juga konsultasi.

\section{Saran}

Kepada pemerintah dan pemangku kepentingan pelaksanaan musyawarah dalam pengadaan tanah untuk kepentingan umum, ada baiknya diatur secara teknis tentang musyawarah tidak hanya berformal-legal saja tetapi lebih dari itu tidak hanya mengesampingkan nilai-nilai esensial dalam musyawarah yang berupa, negosiasi, mediasai dan konsultasi sesuai dengan prinsip yang dianut dalam rezim hukum pertanahan indonesia adalah tiada pengadaan tanah tanpa musyawarah.

\section{Daftar Pustaka}

Buku

Bernhard Limbong, Pengadaan Tanah Untuk Pembangunan ( Regulasi, Kompensasi, Penegakan Hukum, Margaretha Pustaka, Jakarta, 2011.

Maria SW, Sumardjono, Kebijakan Pertanahan Antara Regulasi Dan Implementasi, Kompas, Jakarta, 2001.

Nurul Qamar, Hak Asasi Manusia Dalam Negara Hukum Demokrasi, Jakarta, Sinargrafika, Cetakan Ketiga, 2016.

H.M. Arba, Hukum Pengadaan Tanah Untuk Kepentingan Umum, Sinar Grafika, Jakarta, 2019.

Boedi Harsono, Hukum Agraria Indonesia, Sejarah Pembentukan UndangUndang Pokok Agraria, Isi dan Pelaksanaannya, Djembatan, Jakarta, 1995.

Adrian Sutedi, Implementasi Prinsip Kepentingan Umum Di Dalam Pengadaan Tanah Untuk Kepentingan Umum, Sinar Grafika, Jakarta, 2020. 
Susilawetty, Arbitrase Dan Alternatif Penyelesaian Sengketa Ditinjau Dalam Persepektif Peraturan Perundang - Undangan, Gramata Publishing, Jakarta, 2013.

Jimmy Joses Sembiring, Cara Menyelesaiakan Sengketa Diluar Pengadilan,Trans Media Putaka, Jakarta, 2011.

D.Y. Witanto, Hukum Acara Mediasi Dalam Perkara Perdata Umum Dan Peradilan Agama Menurut Perma NO 1 Tahun 2008 Tentang Prosedur Mediasi Di Pengadilan, Alfabeta,Bandung, 2011.

Ali Sofwan Husein, Komplik Pertanahan, Pustaka Sinar Harapan, Jakarta, 1997.

Yesmil Anwar \& Adang, Pengantar Sosiologi Hukum, Grasindo, Jakarta, Cetakan Ketiga, 2017.

Artikel Jurnal

Koeswahyono, Imam. "Mengkritisi Rancangan Undang-Undang Pengadaan Tanah Untuk Kepentingan Pembangunan, Suatu Catatan Kritis." Jurnal Hukum \& Pembangunan 41.2 (2011): 243-257

\section{Makalah/Pidato}

Suruh Roiqoh, "Pengadaan Tanah Untuk Kepentingan Umum (Kajian Perbandingan Antara Hukum Islam dalam Konsep Maslaha Mursalah dan Undang-Undang Nomor 2 Tahun 2012)", Tesis pada Fakultas Hukum Universitas Islam Indonesia, Yogyakarta, 2013

\section{Peraturan Perundang-Undangan}

Undang-Undang Nomor 5 Tahun 1960 tentang Peraturan Dasar Pokok-Pokok Agraria, Lembaran Negara No. 104 Tahun 1960

Undang-Undang Nomor 2 Tahun 2012 tentang Pengadaan Tanah Bagi Pembangunan Untuk Kepentingan Umum. Peraturan Presiden (Perpres) Nomor 148 Tahun 2015 tentang Perubahan Keempat atas Perpres Nomor 71 Tahun 2012 tentang Penyelenggaraan Pengadaan Tanah Bagi Pembangunan untuk Kepentingan Umum

Undang - Undang No 39 Tahun 1999 Tentang Hak Asasi Manusia

Keputusan presiden Nomor 55 Tahun 1993 Tanggal 10 September tahun 1980 tentang pengadaan tanah bagi pelaksanaan pembagunan untuk kepentingan umum

Peraturan Presiden No 65/2006 Tentang Pengadaan Tanah Bagi Pelakasanaan Untuk Pembangunan Umum; Perpres No 148 Tahun 2015 Tentang Perubahan Keempat Atas Peraturan Presiden No 71 Tahun 2012 Tentang Penyelenggaraan Pengadaan Tanah Untuk Kepentingan Umum 